\title{
Animal and Vegetation Response to Modified Intensive-Early Stocking on Shortgrass Rangeland
}

\author{
Keith R. Harmoney ${ }^{1}$ and John R. Jaeger ${ }^{2}$ \\ Authors are ${ }^{1}$ Associate and ${ }^{2}$ Assistant Professor, Kansas State University, Western Kansas Agricultural Research Center, Hays, KS 67601, USA.
}

\begin{abstract}
A comparison of animal gains and vegetation trends was made from 2002-2008 between a continuous season-long stocking (SLS) system and a modified intensive-early stocking system (IES) with late-season grazing (IES 1.6 $\times+1 ; 1.6$ times the number of animals of the SLS system from May 1 to July 15, and 1 times the number of animals of SLS from July 15 to October 1) on shortgrass native rangeland of western Kansas. The continuous season-long stocked system placed animals at a density of $1.37 \mathrm{ha} \cdot$ steer $^{-1}$ from May through October, or 2.63 animal unit months $(\mathrm{AUM}) \cdot \mathrm{ha}^{-1}$, whereas the intensive-early stocked system with late-season grazing $\left(3.33 \mathrm{AUM} \cdot \mathrm{ha}^{-1}\right.$ ) stocked pastures at $0.85 \mathrm{ha} \cdot$ steer $^{-1}$ from May through the middle of July, and then stocked pastures at $1.37 \mathrm{ha} \cdot$ steer $^{-1}$ for the remainder of the grazing season by removing the heaviest animals mid-July each yr. Average daily gains $\left(0.78\right.$ vs. $\left.0.70 \mathrm{~kg} \cdot \mathrm{d}^{-1}, P=0.039\right)$ and total animal gain $(58 \mathrm{vs.} 52 \mathrm{~kg}, P=0.042)$ were different between the continuous season-long stocked and the intensive-early stocked animals during the first half of the grazing season. No difference was found between average daily gain $\left(0.61 \mathrm{vs.} 0.62 \mathrm{~kg} \cdot \mathrm{d}^{-1}, P=0.726\right)$ and total animal gain (48 vs. $49 \mathrm{~kg}$, $P=0.711)$ for the continuous season-long stocked and intensive-early stocked with late-season grazing animals during the last half of the season. Total individual animal gain (106 vs. $101 \mathrm{~kg}, P=0.154)$ and average daily gain $\left(0.70 \mathrm{vs} .0 .66 \mathrm{~kg} \cdot \mathrm{d}^{-1}\right.$, $P=0.152$ ) was not different between the continuous season-long stocked and the intensive-early stocked system animals that were on pasture the entire grazing season. Total beef gain on a land-area basis ( $96 \mathrm{vs.} 77 \mathrm{~kg} \cdot \mathrm{ha}^{-1}, P=0.008$ ) was greater for the modified intensive-early stocked system with late-season grazing with greater animal densities. Changes in residual biomass and most key vegetation components at the end of the grazing season were not different between the two systems.
\end{abstract}

\section{Resumen}

Se hizo una comparación de la ganancia animal y las tendencias de la vegetación a partir de 2002 hasta el 2008 entre un sistema de pastoreo continuo durante toda la estación (SLS) y un sistema pastoreo modificado del intensivo-temprano con una etapa de pastoreo a fines de temporada (IES $1.6 \times+1$ ) en un pastizal nativo corto en la parte occidental de Kansas. En el sistema de pastoreo de toda la estación se colocaron animales a una densidad de $1.37 \mathrm{ha} \cdot$ novillo $^{-1}$ desde Mayo a Octubre o 2.63 unidad animal mes (AUM) $\cdot$ ha $^{-1}$, mientras que el sistema pastoreo modificado intensivo-temprano con una etapa de pastoreo a fines de temporada $\left(3.33 \mathrm{AUM} \cdot \mathrm{ha}^{-1}\right.$ ) y con una carga animal en los potreros de $0.85 \mathrm{ha} \cdot$ novillo $^{-1}$ desde mayo hasta mediados de Julio, y después los potreros tuvieron una carga de 1.37 ha $\cdot$ novillo $^{-1}$ para el resto de la estación de pastoreo removiendo los animales más pesados a mediados de julio cada año. El promedio de las ganancias $\left(0.78\right.$ vs. $\left.0.70 \mathrm{~kg} \cdot \mathrm{dia}^{-1}, P=0.039\right)$ y una ganancia total por animal $(58 \mathrm{vs} .52 \mathrm{~kg}, P=0.042)$ fueron diferentes entre los animales del sistema de pastoreo continuo de toda la estación y el sistema de pastoreo intensivo-temprano durante la primera mitad de la estación de pastoreo. No se encontró ninguna diferencia entre en el promedio de la ganancia diaria ( 0.61 vs. $0.62 \mathrm{~kg} \cdot \mathrm{dia}^{-1}, P=0.726$ ) y la ganancia total por animal (48 contra $49 \mathrm{~kg}, P=0.711$ ) para los animales del sistema de pastoreo continuo de toda la estación y el sistema de pastoreo intensivo-temprano con la etapa de pastoreo a fines de temporada durante la mitad de la estación de pastoreo. La ganancia individual por animal (106 vs. $101 \mathrm{~kg}, P=0.154)$ y el promedio de la ganancia diaria $\left(0.70\right.$ vs. $\left.0.66 \mathrm{~kg} \cdot \mathrm{dia}^{-1}, P=0.152\right)$ no fue diferente entre el sistema de pastoreo continuo de toda la estación y el sistema de pastoreo intensivo-temprano en los animales que estuvieron en los potreros durante toda la estación de pastoreo. La producción total de carne por área fue $\left(96 \mathrm{vs} .77 \mathrm{~kg} \cdot \mathrm{ha}^{-1}, P=0.008\right)$ y fue mayor para pastoreo modificado intensivo-temprano con la etapa de pastoreo a fines de temporada con una mayor densidad animal. Los cambios en la biomasa y la mayoría de los componentes de la vegetación clave al final de la época de pastoreo no fueron diferentes entre los dos sistemas.

Key Words: basal cover, beef production, litter cover, residual biomass, season-long continuous stocking, stocking systems

\section{INTRODUCTION}

Beef production on western Kansas rangelands is primarily dominated by mature beef cow/calf systems, whereas beef production in eastern Kansas primarily is beef cow/calf systems

Journal Paper 11-113-J of the Kansas Agricultural Experiment Station, Manhattan, KS.

Correspondence: Keith R. Harmoney, Western Kansas Agricultural Research Center, 1232 240th

Ave, Hays, KS 67601, USA. Email: kharmone@ksu.edu

Manuscript received 20 September 2010; manuscript accepted 26 May 2011. and young stocker animal systems. In order to have management flexibility during years of low precipitation, producers in western Kansas can include young stocker animals in their livestock program that can be marketed if seasonal droughts persist, which would allow destocking and restocking rangelands without liquidating their main breeding herd. Stocker cattle on eastern Kansas Flint Hills rangelands historically have had greater gains in May and June than during other periods of the growing season because of greater quality of available spring forage (Launchbaugh and Owensby 1978). In eastern 
Table 1. Mean annual precipitation and growing season precipitation (April through September) for Hays, KS, from 2002 to 2008, along with the 30-yr mean for both parameters.

\begin{tabular}{|c|c|c|c|c|c|c|c|c|}
\hline \multirow[b]{2}{*}{ Precipitation } & \multicolumn{8}{|c|}{ Year } \\
\hline & 2002 & 2003 & 2004 & 2005 & 2006 & 2007 & 2008 & 30-yr mean \\
\hline Total annual & 443 & 599 & 611 & 600 & 473 & 828 & 727 & 576 \\
\hline Deviation from mean & -133 & 23 & 35 & 24 & -103 & 251 & 151 & \\
\hline Growing season total & 332 & 508 & 469 & 361 & 325 & 515 & 495 & 413 \\
\hline Deviation from mean & -81 & 95 & 56 & -53 & -88 & 102 & 82 & \\
\hline
\end{tabular}

Kansas, intensive-early stocking (IES) now is a common practice that stocks young animals at greater densities for the first half of the growing season and then removes the animals for the last half of the growing season, effectively utilizing early-season vegetation at its highest level of nutrition (Owensby et al. 2008). Pounds of beef produced on a landarea basis is consistently greater for pastures using intensiveearly double-stocking $(2 \times$ IES), or pastures stocked at twice the season-long density during the first half of the season, than continuous season-long stocked (SLS) pastures on eastern Kansas and Oklahoma tallgrass rangelands (Smith and Owensby 1978; McCollum et al. 1990). On shortgrass rangeland in western Kansas, individual animal gain during the early growing season, and total beef production on a landarea basis, is similar between animals stocked at $2 \times$ IES and animals stocked at a normal SLS density (Olson et al. 1993). Long-term grazing studies have demonstrated that SLS is sustainable at a moderate rate of 2.5-3.0 animal unit months (AUM) $\cdot \mathrm{ha}^{-1}$ at this location (Launchbaugh 1957, 1967). However, vegetative composition or animal gain data revealed that implementing a triple-stocked IES system at 3.45 AUM $\cdot \mathrm{ha}^{-1}$ (Olson et al. 1993), or SLS at 3.85-4.17 $\mathrm{AUM} \cdot \mathrm{ha}^{-1}$ (Launchbaugh 1957, 1967) was not sustainable at this site. Also, in western Kansas, when implementing a modified IES system, which stocked at a $2 \times$ IES rate during the early season and then removed half of the animals at midseason to finish late-season grazing at a normal $1 \times$ rate $(2 \times+1$ IES), early-season animal gains were $15 \%$ lower than for SLS in 2 out of $4 \mathrm{yr}$, and full-season individual animal gains were $25 \%$ lower for the $2 x+1$ IES system in 3 of $4 \mathrm{yr}$ (Vanzant et al. 1994). A study in eastern Kansas used $2 x+1$ stocking in a 3-yr rotation with SLS and $2 \times$ IES (Owensby et al. 2008). In that study, a $16 \%$ annual increase in stocking rate from the rotation resulted in $30 \%$ greater animal production on a land-area basis without any negative impact on the pasture system vegetation. However, removal of animals halfway through the season was not based on animal weight or removal of the heaviest animals (Owensby et al. 2008). It was hypothesized that by reducing the density of animals early in the season to less than the $2 \times$ IES density, and then removing the heaviest animals at midseason, that a modified $1.6 \times+1$ system (1.6 times the number of animals of the SLS system from May 1 to July 15, and 1 times the number of animals of SLS from July 15 to October 1) would initially 1) retain maximum early-season gain per animal similar to $2 \times$ IES, and 2) retain late-season animal gain similar to season-long stocking, thus 3 ) increase total gain per acre on shortgrass rangeland. It also was hypothesized that desirable vegetation composition and production would decline over time from the modified $1.6 \times+1$ system, and therefore animal gain and production also would decline over time. Removal of the heaviest animals, rather than randomly selected animals, would result in a more uniform animal group ready for feedlot placement. This study was performed to compare annual use of a modified $1.6 \times+1$ IES system with heavy animal removal halfway through the grazing season to continuous SLS for animal performance and resulting changes in vegetative characteristics.

\section{MATERIALS AND METHODS}

\section{Study Site}

The study site was located at the Kansas State University Agricultural Research Center near Hays, KS (lat $38^{\circ} 51^{\prime} 29.8759^{\prime \prime} \mathrm{N}$, long $99^{\circ} 20^{\prime} 06.9770^{\prime \prime} \mathrm{W}$, elevation $611 \mathrm{~m}$ above sea level). Pastures consisted mostly of loamy upland (Typic Argiustolls) range sites with small inclusions of limy upland (Entic Haplustolls) and loamy lowland (Cumulic Argiustolls) range sites. Four pasture replicates, averaging 13.75 ha in size, were used for each stocking system and were blocked by composition of range sites. Dominant grass vegetation of the study site included sideoats grama (Bouteloua curtipendula [Michx.] Torr.), blue grama (Bouteloua gracilis [Willd. ex Kunth] Lag. ex Griffiths), buffalograss (Buchloe dactyloides [Nutt.] Engelm.), western wheatgrass (Pascopyrum smithii [Rydb.] A. Löve), and Japanese brome (Bromus japonicus Thunb. ex Murr.); the key nongrass species were western ragweed (Ambrosia psilostachya DC.) and sedges (Carex spp.). The climate is semi-arid, and approximately $72 \%$ of annual precipitation occurs during the 6-mo period of April through September (Table 1). Three yr of growing season precipitation were at least $50 \mathrm{~mm}$ below normal, whereas $4 \mathrm{yr}$ were more than $50 \mathrm{~mm}$ above normal. Mean annual precipitation for the study site is $576 \mathrm{~mm}$. The average annual frost-free period is $164 \mathrm{~d}$, from 26 April to 10 October.

\section{Stocking Systems}

In 2001, prior to the study, all pastures were stocked with an average of six heifers (mean $340 \mathrm{~kg}$ ) from May through July. From 2002 to 2008, all pastures were stocked with Angus and Angus $\times$ Hereford steers. Animals were withheld from feed and water for 6-12 h and weighed, averaging $279 \mathrm{~kg}$ at grazing initiation. Animals were implanted with Synovex-S $S^{\circledR}$, stratified by weight, and randomly assigned to one of two treatments, SLS (season-long stocking from 1 May to 1 October) or IES 
Table 2. Individual animal gain and animal gain on a land-area basis for a modified intensive-early stocking (IES; $1.6 \times+1)$ system and a continuous season-long stocking (SLS) system on shortgrass rangelands near Hays, KS, from 2002 to 2008. $P$ values less than 0.05 indicate that the stocking strategies within a row were different averaged across yr. Values in parentheses indicate standard errors.

\begin{tabular}{|c|c|c|c|}
\hline Production trait & SLS & IES $1.6 \times+1$ & $P$ value \\
\hline Average daily gain, May-July $\left(\mathrm{kg} \cdot \mathrm{d}^{-1}\right)$ & $0.78(0.04)$ & $0.70(0.03)$ & 0.039 \\
\hline Average daily gain, July-October $\left(\mathrm{kg} \cdot \mathrm{d}^{-1}\right)$ & $0.61(0.03)$ & $0.62(0.03)$ & 0.726 \\
\hline Full season average daily gain, May-October $\left(\mathrm{kg} \cdot \mathrm{d}^{-1}\right)$ & $0.70(0.02)$ & $0.66(0.02)$ & 0.152 \\
\hline Average total steer gain, May-July (kg) & $58(3)$ & $52(2)$ & 0.042 \\
\hline Average total steer gain, July-October (kg) & $48(2)$ & $49(2)$ & 0.711 \\
\hline Full season average total steer gain, May-October $(\mathrm{kg})$ & $106(4)$ & $101(4)$ & 0.154 \\
\hline Steer production $\left(\mathrm{kg} \cdot \mathrm{ha}^{-1}\right)$ & $77(3)$ & $96(4)$ & 0.008 \\
\hline
\end{tabular}

$1.6 \times+1$ (1.6 times the number of animals of the SLS system from 1 May to 15 July, and 1 times the number of animals of SLS from 15 July to 1 October) strategies. The SLS treatment placed animals at a density of $1.37 \mathrm{ha} \cdot$ steer $^{-1}$ during the 5 -mo grazing season of May through October, or $2.63 \mathrm{AUM} \cdot \mathrm{ha}^{-1}$. The IES $1.6 \times+1$ system $\left(3.33 \mathrm{AUM} \cdot \mathrm{ha}^{-1}\right)$ stocked animals at $0.85 \mathrm{ha} \cdot$ steer $^{-1}$ from May through the middle of July, and then stocked at 1.37 ha steer $^{-1}$ for the remainder of the grazing season by removing the heaviest animals mid-July each yr. Each yr, on or about July 14, animals were again held without feed or water and were weighed to identify the heaviest animals in each pasture. The heaviest animals from each IES $1.6 \times+1$ pasture were removed and placed in a feedlot. Animals on pasture after the grazing season midpoint were provided a protein supplement to deliver $0.1 \mathrm{~kg}$ crude protein $\cdot$ steer ${ }^{-1} \cdot \mathrm{d}^{-1}$ through the rest of the grazing season. The supplement was fed in a 50:50 dry rolled milo:soybean meal supplement in 2002, 2005, 2006, and 2008. In 2003, 2004, and 2007 the protein supplement was delivered through molasses-based supplement tubs custom made for the consumption of the desired amount of daily crude protein supplement. Each yr in early October, animals were withheld from feed or water for 6-12 h and weighed. Stocking comparisons were made from 2002 to 2008. Economic data were derived from utilizing a $7 \%$ annual interest rate on the purchase of animals, the animal weight means of each system, and the western Kansas current and historic feeder steer pricing for the first wk of May, third wk of July, and first wk of October (Dhuyvetter 2010) that coincided with the weeks when animal weights were measured. Mixed models of SAS (SAS 1996) were used for statistical analysis of average individual animal performance and of land-area productivity. Statistical models included replication, pasture stocking treatment, yr, and their interactions.

\section{Vegetation Sampling}

Vegetation was sampled at the end of each grazing season from 2001 to 2008. Vegetation from 10 frames, each $0.2 \mathrm{~m}^{2}$, was clipped at ground level above soil litter along transects through each pasture when all animals were removed from pastures in 2002 to 2008. Samples were dried in a forced air oven at $50^{\circ} \mathrm{C}$ for $72 \mathrm{~h}$ to enable calculation of residual dry matter. Furthermore, litter cover, plant basal cover, and plant basal composition were estimated along the same permanent transects spanning each pasture unit by using a modified step point technique (Owensby 1973) at the end of each growing season from late September through October 2001 to 2008. Each transect consisted of 600 random points. Litter cover, plant basal cover, and vegetative composition were analyzed from both raw data and transformed data using arcsin $\sqrt{\text { propor- }}$ tion. Results of the two data sets were similar, and thus nontransformed data are discussed and presented in the text and graphs. Mixed models of SAS (SAS 1996) also were used to test residual dry matter, litter, and vegetative data.

\section{RESULTS}

\section{Steer Production}

Individual steer performance and total beef production were both affected by stocking system and yr, but no stocking system by $\mathrm{yr}$ interaction resulted. Average daily gain $(0.78$ vs. $0.70 \mathrm{~kg} \cdot \mathrm{d}^{-1}$ ) and individual total animal gain (58 vs. $52 \mathrm{~kg}$ ) were different $(P=0.042)$ between the SLS animals and the IES $1.6 \times+1$ animals for the first half of the grazing season (Table 2). Average daily gain (0.61 vs. $\left.0.62 \mathrm{~kg} \cdot \mathrm{d}^{-1}\right)$ and individual total animal gain (48 vs. $49 \mathrm{~kg}$ ) was not different $(P>0.50)$ for the SLS and $1.6 \times+1$ systems, respectively, during the last half of the season (Table 2). Animals from the more densely stocked IES system had lower gains halfway through the season, and had daily gain and total gain similar to animals from the SLS system during the last half of the season. Total individual animal gain (106 vs. $101 \mathrm{~kg})$ and average daily gain $\left(0.70\right.$ vs. $0.66 \mathrm{~kg} \cdot \mathrm{d}^{-1}$; Table 2$)$ was not different $(P=0.15)$ between the SLS and the $1.6 \times+1$ system for animals on pasture the entire 5-mo grazing season. Each yr, total steer gain on a land-area basis (96 vs. $77 \mathrm{~kg} \cdot \mathrm{ha}^{-1}$ ) was greater $(P=0.008)$ for the modified IES system with greater animal densities (Table 2). After deducting initial costs of purchase and interest on grazing animals, return ha ${ }^{-1}$ was greater 2 of $7 \mathrm{yr}$ for the $1.6 \times+1$ system and equal the remaining $5 \mathrm{yr}$, and averaged $\$ 28.99 \mathrm{ha}^{-1}$ greater $(P=0.004)$ across all yr (Table 3).

Animal data also were applied to historic market pricing for the $25 \mathrm{yr}$ (1977 to 2001) prior to the start of this study (Dhuyvetter 2010). The $1.6 \times+1$ system returned an average of $\$ 14.95 \mathrm{ha}^{-1}$ more than the SLS system during that 25 -yr span (data not shown). Both systems had $1 \mathrm{yr}$ of negative returns, and for 22 of the $25 \mathrm{yr}$ the $1.6 \times+1$ system resulted in a greater return than the SLS system. Returns $\mathrm{ha}^{-1}$ ranged from $-\$ 9.02$ to $\$ 145.29$ for the SLS, and from $-\$ 22.70$ to $\$ 189.55$ for the $1.6 \times+1$ system during that 25 -yr period. 
Table 3. Net return on a land-area basis after initial purchase price and interest costs for steers in a modified intensive-early stocking (IES; $1.6 \times+1$ ) system and a continuous season-long stocking (SLS) system on shortgrass rangelands near Hays, KS, from 2002 to 2008. $P$ values less than 0.05 indicate that stocking strategies were different within a row. Values in parentheses indicate standard errors.

\begin{tabular}{lccc}
\hline Year & SLS & IES 1.6×+1 & $P$ value \\
\hline & $89.09(2.76)$ & $85.13(14.36)$ & 0.7558 \\
2002 & $264.31(10.89)$ & $284.96(15.77)$ & 0.1177 \\
2003 & $200.82(5.81)$ & $270.29(13.31)$ & 0.0001 \\
2004 & $140.25(2.44)$ & $158.02(4.95)$ & 0.1744 \\
2005 & $185.72(10.79)$ & $206.84(11.70)$ & 0.1103 \\
2006 & $114.66(9.00)$ & $135.45(9.45)$ & 0.1156 \\
2007 & $55.16(13.84)$ & $112.25(5.61)$ & 0.0003 \\
2008 & $150.00(13.14)$ & $178.99(14.31)$ & 0.0035 \\
Avg & & &
\end{tabular}

\section{Vegetation Trends}

Vegetation trends were analyzed from fall 2001 to fall 2008. Plant basal cover change did not differ between the $1.6 \times+1$ and SLS stocking strategies $(P=0.40$; Fig. 1$)$. Western wheatgrass $(P=0.63)$, blue grama $(P=0.78)$, buffalograss $(P=$ $0.20)$, sideoats grama $(P=0.75)$, and Japanese brome $(P=$ 0.11) composition changes did not differ between stocking systems (data not shown). Composition changes in both stocking systems for each of these species basically paralleled each other over the $7 \mathrm{yr}$. Trends showed that western wheatgrass and blue grama increased in composition by $2 \%$ each $\mathrm{yr}$, and buffalograss increased in composition by $1 \%$ each yr in both stocking systems. Sideoats grama composition did not change, and Japanese brome composition decreased by $5 \%$ to $6 \%$ each yr in both stocking systems over the 7-yr study. Two trends differing between the stocking systems in the present trial were that litter cover decreased at a slightly greater rate $\left(P=0.052 ; 2.1 \% \mathrm{yr}^{-1}\right.$ vs. $\left.1.2 \% \mathrm{yr}^{-1}\right)$ in the $1.6 \times+1$ system than in the continuous SLS system (Fig. 1), and, sedges increased in composition by a total of $2 \%$ over the $7 \mathrm{yr}$ in the $1.6 \times+1$ system, but sedges in the SLS system remained at

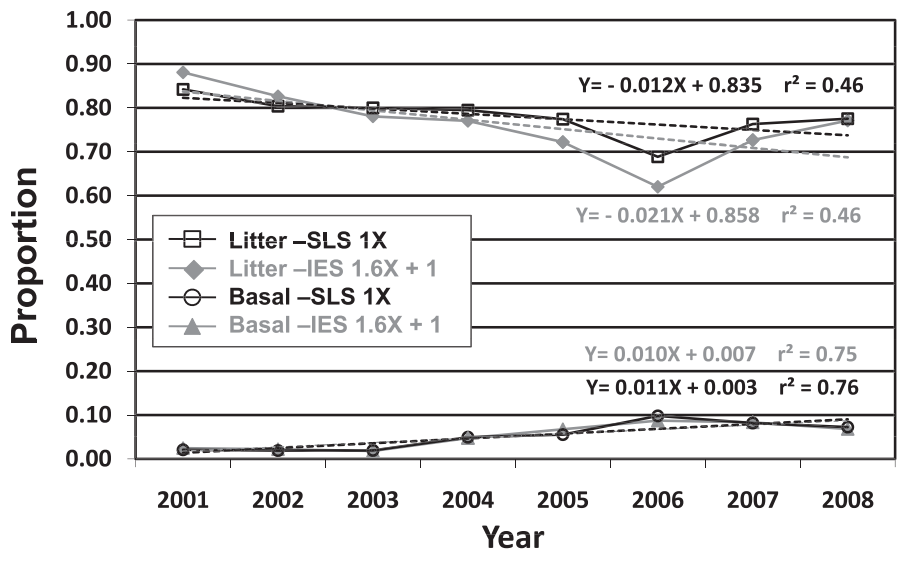

Figure 1. Litter cover and basal cover during a modified intensive-early stocking (IES $1.6 \times+1$ ) or season-long stocking (SLS) system at Hays, KS, from 2001 (yr 0) just prior to the study to 2008 (yr 7) at the end of the study. Dashed lines indicate the linear trend lines across yr.

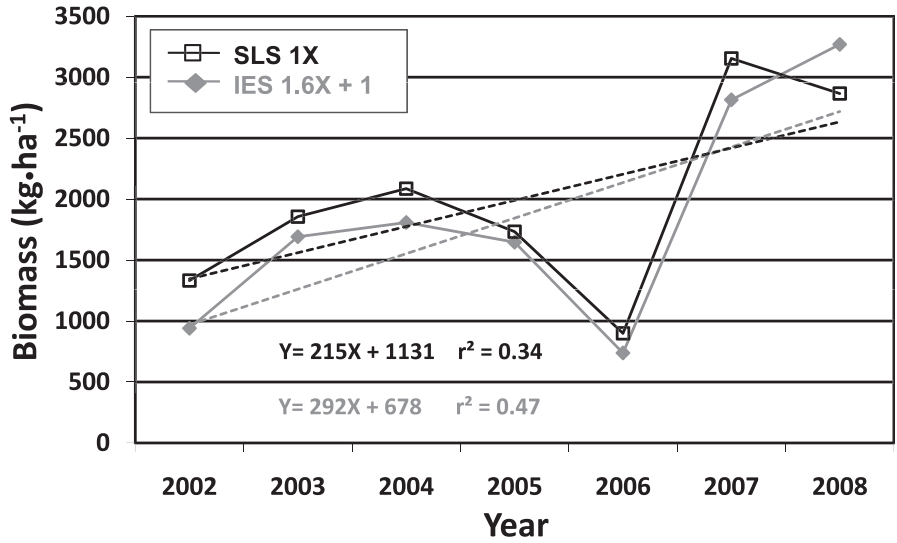

Figure 2. End-of-season residual dry matter biomass following a modified intensive-early stocking (IES $1.6 \times+1$ ) or season-long stocking (SLS) system at Hays, KS, from 2002 (yr 1) to 2008 (yr 7). Dashed lines indicate the linear trend lines across yr.

the same level ( $P=0.04$; data not shown). Total end-of-season residual dry matter biomass averaged over yr was similar between the $1.6 \times+1$ and the SLS treatments in this trial, and the trend in annual change for end-of-season residual dry matter actually increased at a greater rate for the $1.6 \times+1$ stocking because of a residual dry matter increase in 2008 compared to the SLS system (Fig. 2).

\section{DISCUSSION}

\section{Steer Production}

Animals from the modified $1.6 \times+1$ system had lower gains during the early season compared to the SLS system, but animals from double-stocked IES systems on Kansas rangelands have typically had similar early-season gains as animals from SLS (Olson et al. 1993; Owensby et al. 2008), so the depressed early-season gains from the $1.6 \times+1$ system in this study were somewhat unexpected. However, steers in another intensiveearly stocked system on the northern Great Plains also had lower early-season gains than steers in a continuous seasonlong stocked system in 2 out of 3 yr (Grings et al. 2002). Animals in the $1.6 \times+1$ system that remained on pasture season-long had similar total season gain as animals in the SLS system. In a previous trial at this location, late-season gains were $25 \%$ lower 3 of $4 \mathrm{yr}$ for a $2 \times+1$ system than for a SLS system; thus quantity or quality of forage was lacking in the $2 \times+1$ system (Vanzant et al. 1994). Therefore, lowering the density early in the season to a $1.6 \times$ rate and removing the heaviest animals midseason allowed enough quantity and quality of late-season forage for late-season animals to maintain expected individual performance. Animals from both the season-long stocked and the modified intensive-early stocked systems in the current study received a late-season protein supplement; however, the study by Vanzant et al. (1994) did not supplement and might have contributed to the late-season decline in individual animal gain from the modified $2 \times+1$ system.

Owensby et al. (2008) referred to the greater stocking density early in the season as a pasture preconditioning, or removal of early-season growth to allow grazing on more nutritious 
regrowth, resulting in greater animal gain late in the season. Ring et al. (1985) found that animals on shortgrass pastures under a $2 \times$ IES system grazed approximately twice the area of rangeland by midseason compared to animals from a SLS system, thus almost doubling the area of pasture grazed once for regrowth and preconditioning later in the season. The SLS animals in Ring et al. (1985) did continually return to the same grazed locations late in the season to graze regrowth, but also had to expand their grazing area late in the season because regrowth was not sufficient to meet dry matter needs. On these same pastures, Olson et al. (2002) demonstrated that forage quality of steer diets through the midpoint of the growing season was basically similar between the $2 \times$ IES and the continuous SLS systems, and that quality of diets in the last half of the growing season was better than expected for the SLS system and highly dependent on timely rainfall events. Lateseason animal gain in the current study was equal between the $1.6 \times+1$ and SLS systems, and therefore regrowth from the presumed increased area grazed early in the $1.6 \times+1$ system apparently had little effect on late-season gain. Because lateseason diet quality in these pastures might not decline quickly and is dependent on timely precipitation (Olsen et al. 2002), poor late-season gains from season-long grazed steers in a $2 \times+1$ system (Vanzant et al. 1994) suggest that lack of dry matter rather than reduced forage quality is a factor. However, no difference in forage availability was observed between earlyseason double-stocked and SLS pastures in July or October (Olson et al. 1993; Vanzant et al. 1994); thus, the cause for poor late-season animal gain from the $2 x+1$ system on shortgrass pastures (Vanzant et al. 1994) remains unknown and was not observed in the current study or by Owensby et al. (2008) in tallgrass pastures. A contributing factor to poor lateseason gains in the $2 x+1$ system observed by Vanzant et al. (1994) might have been a $10 \%$ loss in relative abundance of western wheatgrass at the conclusion of the trial compared to the season-long stocked system.

Total gain per hectare increased for the $1.6 \times+1$ system as a result of the greater early stocking density rather than greater early- or late-season steer performance. Because the largest animals were removed at midseason from the $1.6 \times+1$ system, this system had a total season stocking rate $23 \%$ greater than SLS, and produced $25 \%$ more beef on a land-area basis. The rotation of $2 \times+1$ with $2 \times$ IES and SLS employed by Owensby et al. (2008) stocked at a total of $16 \%$ greater over the course of the rotation than SLS alone and produced 30\% more beef on a land-area basis. Years of the current study in which the $1.6 \times+1$ system did not return more dollars than the SLS system were a matter of start and midseason market price relationships rather than animal performance and total animal gain.

\section{Vegetation Trends}

Much more variation occurred in composition due to yr and yearly precipitation patterns than to stocking system. Western wheatgrass composition was reduced, and other botanical shifts occurred in a previous trial with annual use of a modified $2 \times+1$ system (Owensby et al. 1995), and western wheatgrass at this same location also declined from spring grazing that was intense but for a much shorter time period (Harmoney 2007).
Litter cover changed more between yr than between grazing treatments, especially from 2005 to 2006, when low precipitation reduced dry matter production and residual dry matter and litter at the end of the grazing season. Greater water infiltration was observed on northern mixed-grass rangeland with 33\% lighter stocking rates (Abdel-Magid 1987), which likely resulted from greater live and dead vegetation attributing to season litter content to inhibit water flow off site (Launchbaugh 1957).

Combined plant basal and litter cover following grazing each yr ranged from $71-85 \%$ and $79-85 \%$ in the $1.6 \times+1$ and SLS treatments respectively, and the greatest difference within a yr between the two stocking strategies was an $8 \%$ lower litter cover for the $1.6 \times+1$ treatment during the drought yr of 2006 (Fig. 1). In grass-dominated patches of northern Patagonia rangeland, the average difference in combined plant and litter cover between the steady grassdominated state to a transition grass and shrub state was approximately 20\% (Chartier and Rostagno 2006). The difference in plant and litter cover between the $1.6 \times+1$ and SLS treatments did not reach this level; therefore, a significant change in ecosystem function and state from implementing the $1.6 \times+1$ system is less likely to occur unless implemented during many consecutive drought yr in which litter decline is more exaggerated.

Although statistically significant, short-term biological impact of the difference in sedge composition due to stocking system also is small. Environmental conditions between yr had a greater impact on sedge composition than did the stocking system. It was hypothesized that less desirable vegetation would eventually increase and less residual dry matter would be available at the end of the season from annual use of the $1.6 \times+1$ system because of greater vegetation removal and lower long-term vigor of grass due to an increased stocking rate. Grazing-induced significant and adverse changes in vegetative composition and dry matter production occurred within $4 \mathrm{yr}$ of altering stocking rates by up to $50 \%$ on these rangelands in previous studies (Launchbaugh 1957; Olson et al. 1993; Vanzant et al. 1994), but adverse changes were not evident following $7 \mathrm{yr}$ of a $23 \%$ increase in stocking rate in this study. The expected difference in residual dry matter between stocking systems due to forage removal by grazing animals, based on an average individual intake level (approximately $1.9 \%$ of body weight) of animals on rangeland reported by Allison et al. (1982), was $160 \mathrm{~kg} \cdot \mathrm{ha}^{-1}$. The average actual measured difference in residual dry matter was $145 \mathrm{~kg} \cdot \mathrm{ha}^{-1}$. Increased grazing pressure has been demonstrated to increase efficiency of grazing (Smart et al. 2010). Therefore, a greater proportion of the total amount of forage that disappeared from the modified $1.6 \times+1$ stocking system could have been consumed by the grazing animals to fulfill their needs, whereas a lower proportion of forage could have disappeared as a result of trampling, senescence, and use by wildlife and insects. This concept might partially explain the lack of difference in end-ofseason residual standing vegetation between the two stocking methods. Biologically, adverse vegetative or ecosystem changes did not occur during the time frame of this study due to the $1.6 \times+1$ system, but, as indicated by litter cover in 2006, several consecutive seasons of drought could change these relationships. 


\section{MANAGEMENT IMPLICATIONS}

With little evidence that the modified intensive-early stocking system with late-season grazing altered vegetation after seven growing seasons, it might be a useful alternative to continuous season-long stocking that could be implemented during shortterm consecutive seasons, such as in this study. Furthermore, it also might be useful in a rotation of years with continuous season-long stocking or conventional intensive-early doublestocking systems stocked at a moderate rate, as was found by Owensby et al. (2008), but has yet to be analyzed in shortgrass rangelands when used in this manner. Because several years of rangeland production and vegetative composition data are required to assess long-term sustainability, it is not known how long rangelands can support annual use of this practice without any adverse effects. After $7 \mathrm{yr}$, the modified intensive-early stocking system appears to be a viable alternative to continuous season-long stocking to increase animal production on a landarea basis without negatively impacting rangeland vegetative characteristics. The modified intensive-early stocking system provides another option for producers in western Kansas to include stocker animals in their management program and to have more flexibility in preparation for drought.

\section{LITERATURE CITED}

Abdel-Magid, A. H., G. E. Schuman, and R. H. Hart. 1987. Soil bulk density and water infiltration as affected by grazing system. Journal of Range Management 40:307-309.

Allison, C. D., M. M. Kothmann, and L. R. Rittenhouse. 1982. Efficiency of forage harvest by grazing cattle. Journal of Range Management 35:351-354.

Chartier, M. P., and C. M. Rostagno. 2006. Soil erosion thresholds and alternative states in northeastern Patagonian rangelands. Rangeland Ecology \& Management 59:616-624.

DhuYvetTeR, K. C. 2010. Weekly Dodge City feeder cattle and western Kansas slaughter cattle prices.xls. Available at: http://www.agmanager.info/livestock/ marketing/database/cattle/wkcatpr.xls. Accessed 23 March 2010.

Grings, E. E., R. K. Heitschmidt, R. E. Short, and M. R. Haferkamp. 2002. Intensiveearly stocking for yearling cattle in the Northern Great Plains. Journal of Range Management 55:135-138.
Harmoney, K. R. 2007. Grazing and burning Japanese brome (Bromus japonicus) on mixed grass rangelands. Rangeland Ecology \& Management 60:479-486.

LaunchBaugh, J. L. 1957. The effect of stocking rate on cattle gains and on native shortgrass vegetation in west-central Kansas. Kansas Agricultural Experiment Station, Manhattan, KS, USA. Bulletin 394. 29 p.

Launchbaugh, J. L. 1967. Vegetation relationships associated with intensity of summer grazing on a clay upland range site in the Kansas 20- to 24-inch precipitation zone. Kansas Agricultural Experiment Station, Manhattan, KS, USA. Technical Bulletin 154. 24 p.

LaunChBAugh, J. L., AND C. E. OwensBy. 1978. Kansas rangelands: their management based on a half century of research. Kansas Agricultural Experiment Station, Manhattan, KS, USA. Bulletin 622. 56 p.

McCollum, F. T., R. L. Gilleen, D. M. Engle, and G. W. Horn. 1990. Stocker cattle performance and vegetation response to intensive-early stocking of cross timbers rangeland. Journal of Range Management 43:99-103.

Olson, K. C., J. R. Brethour, and J. L. Launchbaugh. 1993. Shortgrass range vegetation and steer growth response to intensive early stocking. Journal of Range Management 46:127-132.

Olson, K. C., J. R. Jaeger, J. R. Brethour, and T. M. Avery. 2002. Steer nutritional response to intensive-early stocking on shortgrass rangeland. Journal of Range Management 55:222-228.

OwensBy, C. E. 1973. Modified step-point system for botanical composition and basal cover estimates. Journal of Range Management 26:302-303.

Owensby, C. E., L. M. Auen, H. F. Berns, and K. C. Dhuyvetter. 2008. Grazing systems for yearling cattle on tallgrass prairie. Rangeland Ecology \& Management 61:204-210.

Owensby, C., R. Cochran, K. Anderson, E. Smith, and E. Vanzant. 1995. 50 years of range research revisited. Kansas Agricultural Experiment Station, Manhattan, KS, USA. Publication 138_1. $118 \mathrm{p}$.

Ring, C. B., II, R. A. Nicholson, and J. L. Launchbaugh. 1985. Vegetational traits of patch-grazed rangeland in west-central Kansas. Journal of Range Management 38:51-55.

SAS. 1996. SAS Systems for Mixed Models. SAS Institute, Inc. Cary, NC, USA: SAS Institute Inc. $633 \mathrm{p}$.

Smart, A. J., J. D. Derner, J. R. Hendrickson, R. L. Gillen, B. H. Dunn, E. M. Mousel, P. S. Johnson, R. N. Gates, K. K. Sedivec, K. R. Harmoney, J. D. Volesky, and K. C. Olson. 2010. Effects of grazing pressure on efficiency of grazing on North American Great Plains rangelands. Rangeland Ecology \& Management 63:397-406.

Smith, E. F., And C. E. OWensby. 1978. Intensive-early stocking and season-long stocking of Kansas Flint Hills range. Journal of Range Management 31:14-17.

Vanzant, E. S., K. C. Olson, J. R. Jaeger, and J. R. Brethour. 1994. Evaluation of stocker grazing strategies on cattle performance and rangeland productivityfour year summary. Kansas Agricultural Experiment Station, Manhattan, KS, USA. Report of Progress 706. 33 p. 